\title{
PENDIDIKAN PERAWATAN JENAZAH BAGI PEREMPUAN DI KECAMATAN TEMBARAK KABUPATEN TEMANGGUNG
}

\author{
Hidayatun Ulfa ${ }^{1 *}$, Sholeh Kurniandini ${ }^{2}$, Misbachul Munir ${ }^{1}$ \\ ${ }^{1}$ Jurusan Syariah, Sekolah Tinggi Agama Islam Nahdlatul Ulama Temanggung \\ Jalan Suwandi Suwardi Km. 1 Temanggung \\ ${ }^{2}$ Jurusan Tarbiyah, Sekolah Tinggi Agama Islam Nahdlatul Ulama Temanggung \\ Jalan Suwandi Suwardi Km. 1 Temanggung \\ "Email: hidayatunulfa52@gmail.com
}

\begin{abstract}
Abstrak
Perawatan terhadap jenazah tidaklah mudah. Untuk melakukannya dibutuhkan keahlian khusus. Mujahizah adalah istilah bagi perawat jenazah perempuan. "Pendidikan Perawatan Jenazah Bagi Perempuan di Kecamatan Tembarak Kabupaten Temanggung” diharapkan mampu meningkatkan kualitas mujahizah (perawat jenazah perempuan) di wilayah Kecamatan Tembarak Kabupaten Temanggung, khususnya dalam hal memandikan dan mengafani jenazah perempuan. Langkah-langkah yang dilakukan dalam Pendidikan Perawatan Jenazah bagi perempuan ini dilakukan melalui FGD, pelatihan perawatan jenazah, praktik memandikan dan mengafani jenazah, serta pendampingan. Karakter yang harus dimiliki oleh mujahizah diantaranya mereka harus sehat jasmani dan rohani, kuat dan tangguh, cakap dan sigap, terampil, berani, cerdas, bijaksana, dan amanah. Setelah dilakukan pelatihan perawatan jenazah kepada mujahizah di wilayah Kecamatan Tembarak Kabupaten Temanggung, para mujahizah memperoleh pendidikan lebih tentang bagaimana merawat jenazah sessuai syariat Islam. Selain itu, mereka juga lebih percaya diri ketika terjun di masyarakat untuk membantu dalam merawat jenazah perempuan.
\end{abstract}

Kata Kunci: Pendidikan, Perawatan Jenazah, Perempuan, Kecamatan Tembarak.

\section{PENDAHULUAN}

Pendidikan diidentikkan dengan buku, belajar di kelas, guru dan segala sesuatu yang berhubungan sengan sekolah secara formal. Dalam KBBI, pendidikan adalah proses pengubahan sikap dan tata laku seseorang atau kelompok orang dalam usaha mendewasakan manusia melalui upaya pengajaran dan pelatihan. Pada pengabdian kali ini, pendidikan yang dimaksud adalah pendidikan terkait perawatan jenazah, khususnya bagi kaum perempuan.

Pengetahuan tentang perawatan jenazah dipandang sebelah mata oleh kebanyakan orang. Hal ini disebabkan karena peristiwa meninggalnya seseorang tidak setiap hari terjadi dan tidak terduga datangnya. Oleh karena itu, ketika ada orang meninggal (sripah), biasanya modin setempat selalu mengambil peran penting di dalamnya. Ketika di lapangan, jenis kelamin orang yang meninggal tidak melulu leki-laki, bagaimana jika orang yang meninggal adalah perempuan? Apakah modin setempat yang akan mengambil peran di dalamnya juga? Hal ini yang menjadikan sebuah keprihatinan ketika minimnya perempuan yang menguasai pengetahuan tentang perawatan jenazah. Berawal dari keprihatinan tersebut, pengabdian terkait pendidikan perawatan jenazah bagi perempuan di Kecamatan Tembarak Kabupaten Temanggung ini perlu dilakukan.

Kecamatan Tembarak adalah salah satu dari 20 kecamatan di wilayah Kabupaten Temanggung. Jarak Kecamatan Tembarak dari Kota Temanggung $8 \mathrm{Km}$. Luas Kecamatan Tembarak 2.684 Ha. Dalam pembagian wilayah administrasi, Kecamatan Tembarak kabupaten Temanggung terbagi menjadi 13 desa, 73 dusun, 223 RT, 63 RW, dengan jumlah Kades 13, perangkat desa 75 dan anggota BPD 44. Jumlah penduduk di Kecamatan Tembarak sebanyak 30.305 orang beragama Islam, 23 orang beragama Kristen, dan 5 orang beragama Katholik (Badan Statistik Temanggung, 2017).

Berdasarkan jumlah dusun yang ada di Kecamatan Tembarak, yakni 73 dusun, maka masingmasing dusun di Kecamatan Tembarak idealnya sudah mempunya tim atau komunitas perawat jenazah yang selalu siap siaga jika sewaktu-waktu ada orang yang meninggal. Jika yang meninggal adalah orang laki-laki, di setiap dusun sudah ada modin. Bagaimana jika yang meninggal adalah perempuan, apakah ada istilah modinah? Inilah mengapa pengabdian ini penting penting dilakukan 
dengan harapan nantinya ditemukan istilah baru bagi perawat jenazah perempuan. Selain itu alasan dilakukan pengabdian ini adalah untuk mengetahui bagaimana pendidikan perawatan jenazah bagi perempuan di Kecamatan Tembarak Kabupaten Temanggung. Dari proses tersebut, nantinya akan dapat diketahui karakter apa saja yang harus dimliki oleh perawat jenazah khususnya bagi perempuan di Kecamatan Tembarak Kabupaten Temanggung.

Jenazah dalam bahasa Arab berasal dari kata janaza-jināzatu yang berarti mayat dalam usungan beserta yang mengantarkan, perarakan mayat (Munawwir, 1997: 214). Dalam Kamus Besar Bahasa Indonesia, jenazah berarti mayat (KBBI, 2016: 203). Merawat jenazah tidaklah mudah bagi sebagian besar orang. Ada empat hal yang harus dilakukan dalam merawat jenazah yakni, memandikan, mengafani, menyalati, dan mengubur jenazah (Kandepag Temanggung, 2013).

Hukum memandikan jenazah/mayat orang yang beragama islam adalah wajib dan pelaksanaannya adalah fardhu kifayah. Jika sebagian ummat telah melaksanakannya, maka terlepaslah kewajiban yang lainnya (Kandepag Temanggung, 2013: 3-6).

Beberapa syarat orang yang memandikan jenazah diantaranya:

a. Dia seorang muslim, berakal dan baligh (dewasa)

b. Niat memandikan jenazah

c. Terpercaya, amanah, mengetahui hukum memandikan mayat dan memandikannya sebagaimana yang diajarkan sunnah dan tidak menyebutkan kepada orang lain aibnya, akan tetapi merahasiakannya apa yang dilihatnya tentang yang tidak baik.

d. Adanya kabar duka tentang meninggalnya seseorang, mengharuskan bagi orang-orang di sekitarnya untuk sesegera mungkin dalam mengurus jenazah tersebut.

Adapun cara memandikan jenazah adalah sebagai berikut:

a) Wajib menutup badannya dari pusar sampai lutut.

b) Mandikan pada tempat yang tertutup.

c) Pakailah sampul tangan dan bersihkan mayat dari segala kotorannya.

d) Ganti sampul tangan yang baru, lalu bersihkan seluruh badannya dan tekan perutnya perlahan-lahan, jika mayat tidak hamil dan baik bila di dekatnya diberi wangi-wangian, agar tidak tercium kalau ada bau yang tidak enak keluar dari mayat itu.

e) Tinggikan bagian kepala dari mayat, agar air tidak mengalir ke bagian kepala

f) Masukkan jari tangan yang telah dibalut dengan kain basah ke mulut mayat, gosok gigi dan bersihkan hidungnya, kemudian mulailah memandikannya dengan mendahului anggota wudhu', jangan dimasukkan air ke mulut atau ke hidungnya.

Harus diingat, bahwa bila mayat sudah dimandikan, tidak ada lagi istilah batal buatnya, karena segala yang membatalkan (wudhu'), bagi yang hidup tidak berlaku lagi untuk si mayat.

g) Siramkan air ke tubuh yang sebelah kanan, sambil membersihkannya, di bagian belakang dan perut, hingga ke ujung kaki. Kemudian sebelah kirinya seperti yang pertama, lalu bersihkan kepalanya, jenggot dan kumisnya.

h) Mandikan mayat dengan air sabun untuk membersihkan badan, dan pada air mandinya yang terakhir diberi wangi-wangian.

i) Sewaktu memandikan mayat, perlakukanlah dia dengan lembut, ketika membalik, menggosok anggota tubuhnya, menekan perutnya, melembutkan sendi-sendinya dan segala sesuatu yang dilakukan, sebagai memuliakannya.

j) Memandikan mayat satu kali, jika bisa membasahi seluruh tubuhnya, itulah yang wajib. Dan sunnah mengulanginya beberapa kali dalam bilangan ganjil.

k) Jika keluar dari mayat itu najis setelah dimandikan dan mengenai badannya, wajib dibuang dan dimandikan kembali, sampai lima sampai tujuh kali. Jika keluar najis setelah diletakkan di atas kain kafannya, tidak diulang lagi mandinya, dan cukup dengan membunag najisnya saja.

1) Keringkan tubuh mayat setelah dimandikan dengan kain atau handuk, hingga tidak membasahi kafannya.

m) Setelah selesai mandi (sebelum dikafani) berilah wangi-wangian di kepala dan jenggot mayat, dengan wangi-wangian yang tidak mengandung alcohol. Kemudian pasangkan juga kepada anggota tubuh yang sujud; kening, hidung, dua telapak tangan, dua lutut dan kedua 
kakinya, juga di telinga dan di bawah ketiaknya, dan baiknya wangi-wangian itu kapur barus.

n) Perlu diingat, sebelum mayat akan dimandikan, siapkanlah dahulu segala keperluankeperluan mandi, sehingga ketika sedang memandikan tidak tertunda akibat kekurangan sesuatu, seperti:

$>$ Tempat memandikan, pada ruang yang tertutup.

$>$ Air secukupnya.

$>$ Sabun, air kapur barus dan wangi-wangian.

$>$ Sarung tangan untuk yang memandikan sekurang-kurangnya dua setel.

> Potongan dan gulungan kain kecil-kecil, kain basahan dan handuk, dan lain-lain yang dianggap perlu.

Dalam buku "Pelatihan Pembinaan Agama Islam" yang dicetak Kandepag Kabupaten Temanggung (2013: 7-8), mengafankan mayat muslim dan bukan mati syahid dalam peperangan, adalah fardhu kifayah, yaitu jika sebagian orang melaksanakannya, maka gugurlah kewajiban yang lainnya. Kewajiban pengafanannya itu serta segala keperluannya sampai kepada penguburan, diambil dari harta si mayat khusus dari yang sudah dikeluarkan dari hak milik lainnya. Jika si mayat tidak mempunyai harta khusus untuk itu, maka yang wajib membiayainya adalah orang yang patut memberinya nafkah ketika dia hidup.Jika tidak ada yang demikian maka diambil dari harta baitul mal ummat islam. Jika ini tidak juga ada, maka kewajiban terpikul pada seluruh ummat islam yang mampu menyelesaikan segala urusannya.

Ada perbedaan aturan penggunaan kain kafan untuk jenazah laki-laki, jenazah perempuan, dan jenazah anak-anak. Kain kafan laki-laki terdiri dari tiga lembar kain putih, tidak pakai baju maupun tutup kepala dan boleh dikafankan dengan dua lembar kain dan sekurang-kurangnya satu lembar yang dapat menutup seluruh badan mayat itu. Adapun kain kafan untuk jenazah anak-anak, kafannya dengan satu lembar kain putih dan boleh jika dikafankan dengan tiga lembar.

Untuk jenazah perempuan, kain kafan terdiri dari lima lembar kain putih yang terdiri atas:

a. Lembar pertama yang paling bawah untuk menutupi seluruh badannya yang lebih lebar.

b. Lembar kedua kerudung kepala.

c. Lembar ketiga untuk baju kurung.

d. Lembar keempat kain untuk menutup dari pinggang hingga kaki.

e. Lembar kelima kain untuk menutup pinggul dan paha.

Urutan ini adalah urutan menata kain kafan. Kalau tidak cukup untuk kain-kain tersebut di atas, kafankan dengan kain sekedar dapat menutupi seluruh badan si mayat, seperti yang tersebut pada pengafanan mayat laki-laki. Cara mengafankan jenazah perempuan, yakni sebagai berikut:

1. Susunlah kain kafan yang sudah dipotong-potong untuk masing-masing bagian dengan tertib, kemudian angkatlah mayat dalam keadaan tertutup dengan kain dan letakkan di atas kain kafan sejajar dan taburi dengan wangi-wangian atau kapur barus. Semua potongan-potongan itu sebelumnya hendaklah diukur panjang dan lebarnya yang cukup untuk si mayat, agar tidak berlebih-lebihan dan mubadzir.

2. Ikatkan kain penutup kedua pahanya. (urutan nomor 5)

3. Pasang kain sarungnya. (urutan nomor 4)

4. Pasangkan baju kurungnya. (urutan nomor 3)

5. Dandanlah rambutnya tiga dandanan (3 kepang), lalu julurkan ke belakang.

6. Pakaikan tutup kepalanya. (urutan nomor 2)

7. Membungkusnya dengan kain pembungkus yang terakhir, dengan cara; temukan kedua pinggir kain kiri dan kanan, lalu digulung ke dalam. Setelah itu diikat dengan sobekan pinggir kain kafan yang sebelumnya telah disediakan di bagian kain bawah tiga atau lima ikatan, dan dilepaskan ikatannya setelah diletakkan di dalam kuburan.

Setelah mayat selesai dikafankan, letakkanlah ia membujur dengan posisi telentang dan sisi kanannya ke arah qiblat, dalam posisi siap untuk disahalatkan. Pendidikan perawatan jenazah bagi perempuan dalam penelitian ini dibatasi pada memandikan dan mengafani jenazah. Hal ini dilakukan karena dua hal tersebut dipandang memerlukan keahlian tersendiri dalam melakukannya. 
Adapun menyalati jenazah bisa dilakukan bersama-sama, sedangkan mengubur jenazah dilakukan oleh kaum laki-laki.

Tujuan pengabdian terkait pendidikan perawatan jenazah bagi perempuan di Kecamatan Tembarak Kabupaten Temanggung ini adalah untuk meningkatkan pengetahuan perawatan jenazah bagi perempuan di wilayah Kecamatan Tembarak Kabupaten Temanggung. Selain itu, pengabdian ini juga bertujuan untuk memberikan dorongan dan motivasi agar kaum perempuan bisa, mampu, dan berani dalam praktik memandikan dan mengafani jenazah yang sesungguhnya.

\section{METODE}

Metode yang digunakan dalam Pendidikan Perawatan jenazah bagi Perempuan di Kecamatan Tembarak ini dilakukan dengan menggunakan model pengabdian berbasis ABCD (Asset Bassed Community Development). Prinsip ABCD adalah kemampuan masyarakat untuk menemukenali aset, kekuatan, dan potensi yang mereka miliki mampu menggerakkan dan memotivasi mereka untuk melakukan perubahan (Panduan KKN ABCD, 2015). Adapun Langkahlangkah yang dilakukan adalah sebagai berikut:

1. Komunikasi Awal

Komunikasi awal dilakukan bersama stakeholder terkait. Karena objek sasaran dalam pengabdian ini adalah kaum perempuan, maka komunikasi awal dilakukan dengan silaturrahim di penasehat Fatayat Anak Cabang Tembarak.

2. Focus Group Discussion (FGD)

FGD dilakukan untuk mendapatkan data awal bersama stakeholder.

3. Perencanaan Pelatihan

Perencanaan pelatihan terkait pendidikan perawatan bagi perempuan di Kecamatan Tembarak.

4. Pelaksanaan Pelatihan

Pelaksanaan pelatihan terkait pendidikan perawatan bagi perempuan di Kecamatan Tembarak.

5. Monitoring dan Evaluasi

Monitoring dan evaluasi dari pelatihan perawatan jenazah dilakukan melalui pendampingan pembuatan video tutorial memandikan dan mengafani jenazah.

6. Ekspose Hasil

Pengabdian di ekspose pada media cetak.

Kegiatan terkait pembinaan keahlian perawatan jenazah di wilayah Kecamatan Tembarak Kabupaten Temanggung dilaksanakan sejak bulan April hingga September 2019. Tim pengabdian melakukan komunikasi dengan ibu sesepuh yang dituakan di wilayah Kecamatan Tembarak, Ibu Zumratul, S.Pd., selaku penasehat fatayat di Anak Cabang Tembarak. untuk selanjutnya dipertemukan dalam FGD.

FGD dilakukan untuk mendapatkan data awal bersama stakeholder. Adapun pihak-pihak yang diajak untuk diskusi intensif terkait dengan kegiatan pengabdian antara lain Ketua Fatayat Ancab Tembarak, Kepala Sekolah SMA Islam Sudirman Tembarak, JFU Pengelola data dan Administrasi Seksi Bimas Islam Kemenag Kabupaten Temanggung, Ketua Jurusan Syariah STAINU Temanggung, dan Tim Pengabdian STAINU Temanggung.

Dari hasil FGD diperoleh data terkait asset yang dimiliki oleh fatayat di Kecamatan Tembarak, yakni masing-masing dusun di Kecamatan Tembarak sudah ada SDM yang mumpuni terkait perawatan jenazah, akan tetapi belum ada standarisasi antar kelompok. Selain itu, dalam FGD tersebut disepakati adanya istilah baru bagi perawat jenazah perempuan, dengan sebutan mujahizah. Oleh karena itu, perlu diadakan pelatiahan terkait pendidikan perawatan jenazah bagi mujahizah.

Selanjutnya, kegiatan pelatihan akan dilaksanakan dua tahap pada bulan Agustus 2019 di SMA Islam Sudirman Tembarak. Tahap pertama adalah pelatihan tentang pengetahuan perawatan jenazah. Pokok pembahasan yang disampaikan oleh nara sumber adalah bagaimana memperlakukan orang yang sedang menghadapi sakaratul maut, apa yang harus dilakukan ketika seseorang dinyatakan sudah meninggal, hukum dan segala sesuatu yang berkaitan dengan 
memandikan jenazah, mengafani jenazah, menyalati jenazah, mengiring jenazah, dan mengubur jenazah.

Tahap kedua adalah pelatihan tentang praktik perawatan jenazah. Masih dengan nara sumber yang sama, pada praktik pelatihan perawatan jenazah ini dibatasi hanya praktik memandikan dan mengafani jenazah.

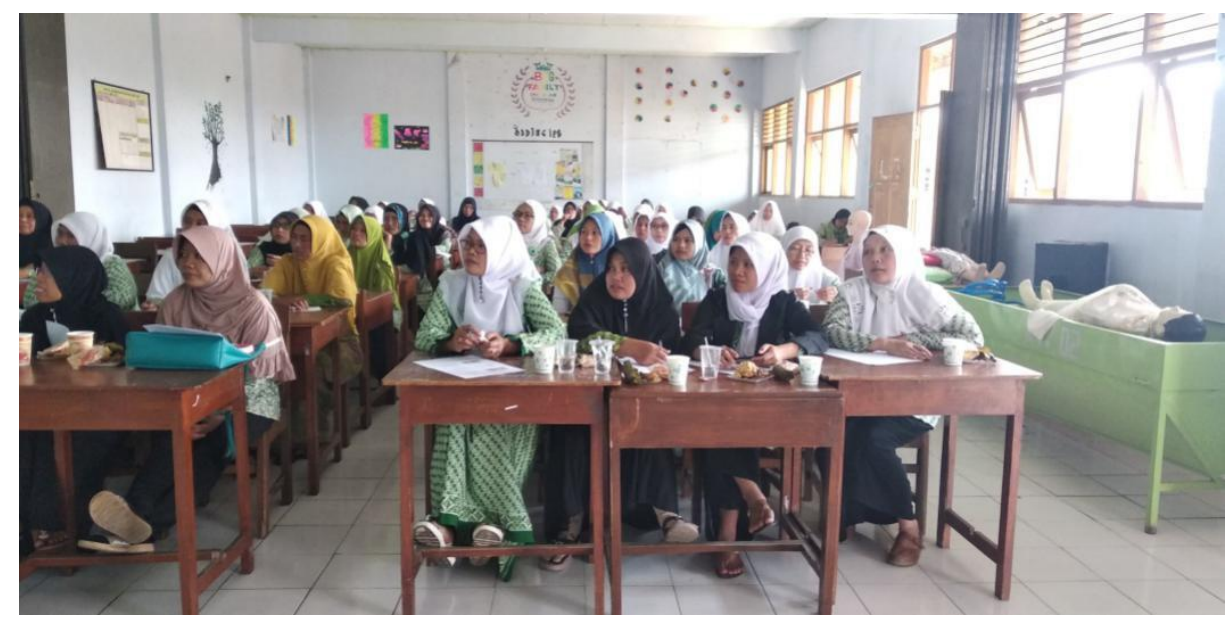

Gambar 1. Suasana Pelatihan Perawatan Jenazah

Praktik dilakukan dengan alat bantu peraga. Parktik yang dilakukan adalah praktik memandikan jenazah dan praktik mengafani jenazah. Praktik berjalan berdasarkan pengetahuan yang diperoleh dalam penjelasan pada pelatihan perawatan jenazah sebelumya. Berikut rangkaian praktik perawatan jenazah:

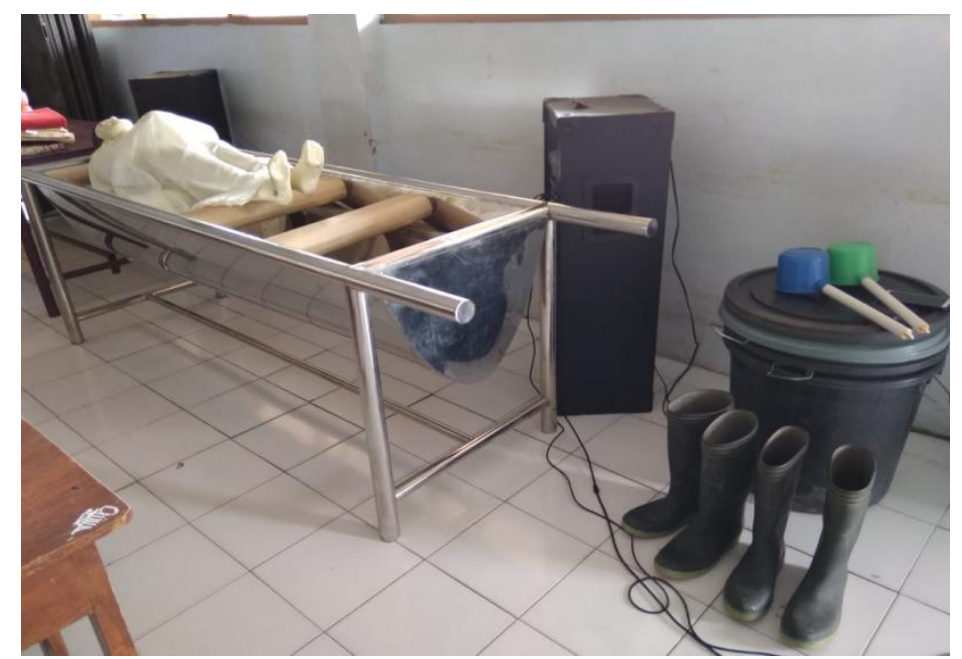

Gambar 2. Peralatan yang digunakan untuk praktik perawatan jenazah 


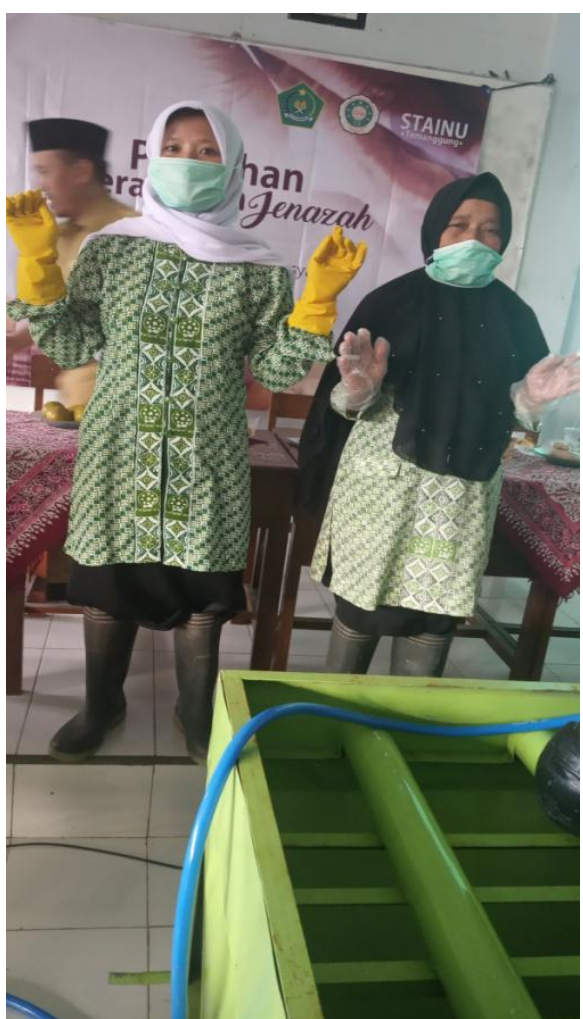

Gambar 3. Atribut dalam praktik memandikan jenazah

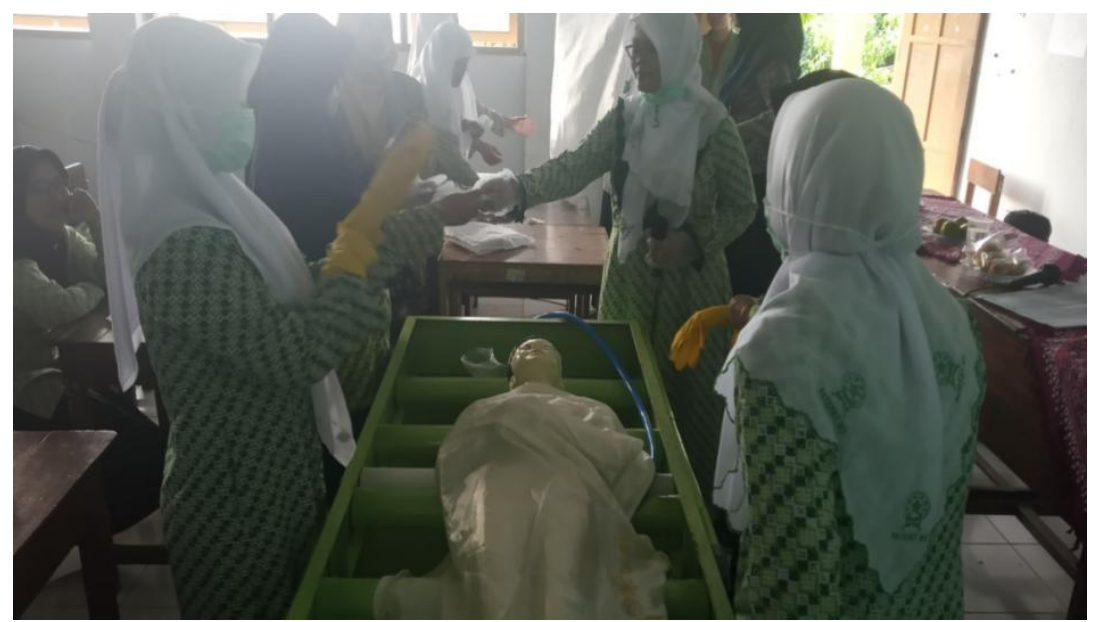

Gambar 4. Suasana ketika praktik memandikan jenazah dengan alat peraga

Untuk praktik mengafani, peserta diberikan contoh bagaimana memotong kain kafan untuk membungkus jenazah. Selain kain kafan, ada juga perlengkapan yang harus ada ketika mengafani jenazah, yakni handuk, kapas, bedak, sisir, gunting (untuk memotong kin kafan), kapur barus, parfum, dan lilin (dipasang di kaki-kaki meja sebelum jenazah dishalatkan atau menunggu jenazah dikuburkan. 


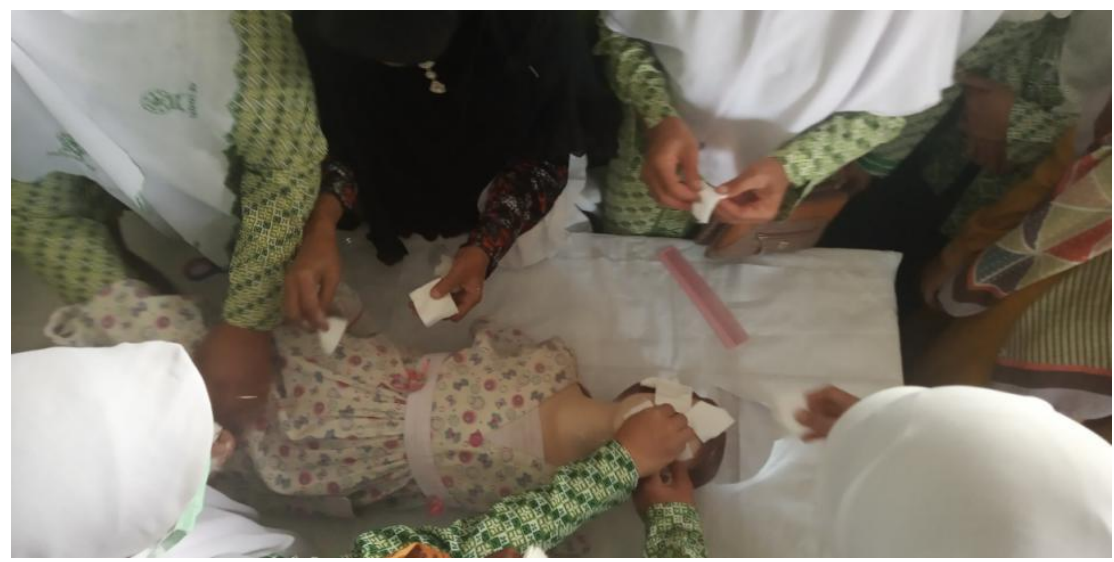

Gambar 5. Suasana praktik mengafani jenazah

Monitoring dilakukan dalam bentuk pendampingan. Pendampingan dilakukan melalui pembuatan video tutorial perawatan jenazah. Adapun dalam pembuatan video tutorial ini, tim pengabdian membantu dalam mendokumentasikannya. Video tutorial dapat dilihat pada: https://drive.google.com/file/d/1u5Y9nQ5aekn15um616V_dwYwKd-NC9Xn/view?usp=drivesdk.

Pengabdian ini diekspose di beberapa media cetak, antara lain:

$>$ http://maarifnujateng.or.id/2019/08/tim-pengabdian-stainu-temanggung-gelarpembinaan-perawatan -jenazah/

$>$ http://www.tabayuna.com/2019/08/tim-pengabdian-stainu-gelar-pembinaan.html

$>$ http://www.hariantemanggung.com/2019/08/di-tembarak-tim-pengabdian-stainutemanggung-gelar-pembinaan-perawatan-jenazah.html

$>$ http://www.pcnutemanggung.or.id/tim-pengabdian-stainu-temanggung-gelarpembinaan-perawatan-jenazah/

$>$ https://drive.google.com/file/d/1u5Y9nQ5aekn15um616V dwYwKdNC9Xn/view? usp $=$ drivesdk

\section{HASIL DAN PEMBAHASAN}

Sebagaimana telah disepakati dalam FGD, istilah bagi perawat jenazah bagi perempuan disebut dengan sebutan mujahizah. Secara kelembagaan, memang mujahizah tersebut belum mempunyai badan koordinasi resmi seperti Badan Koordinasi TPQ misalnya. Akan tetapi, secara tidak langsung mujahizah yang ada di wilayah Kecamatan Tembarak adalah mereka yang tergabung dalam fatayat. Meskipun belum mempunyai wadah, keterampilan mujahizah dalam merawat jenazah harus bisa dipertanggungjawabkan, bukan saja di dunia tetapi juga tanggung jawab di akhirat kelak. Brand image yang terbangun di masyarakat bahwa mujahizah adalah tugas ibu-ibu yang tidak mempunyai 'pekerjaan' dan biasa dilakukan oleh ibu-ibu yang dituakan di suatu tempat dan memang usianya benar-benar tua adalah salah besar. Harus digarisbawahi bahwa menjadi mujahizah bukanlah hal yang mudah dan belum tentu semua orang mampu melakukannya. Apalagi mujahizah juga harus kuat, kuat jasmani dan rohani. Mujahizah yang masih muda mempunyai tenaga yang lebih kuat dibanding mujahizah yang sudah sepuh-sepuh. Dengan demikian, mereka mampu mengangkat dan menjunjung jenazah secara bersama-sama.

Berdasarkan pelatihan yang telah dilakukan, maka idealnya sebuah dusun mempunyai kelompok-kelompok mujahizah yang terampil dan mumpuni. Meskipun legalitasnya tidak diakui secara tertulis, akan tetapi masing-masing dusun harus mempunyai kelompok-kelomok tersebut. Mujahizah harus cakap dan sigap ketika ada orang yang meninggal, bahkan sebelum meninggal (menjelang sakaratul maut) sampai seseorang diyatakan benar-benar sudah meninggal.

Mujahizah juga harus terampil dan berani ketika memandikan jenazah. Keterampilan mujahizah dalam memandikan jenazah terlihat bagaimana mereka mampu memandikan jenazah sebagaimana syariat yang telah ditentukan. Dengan demikian, terciptalah suasana yang tenang dan khidmat saat memandikan jenazah. Keberanian mujahizah dalam memandikan jenazah adalah ketika mereka melihat jenazah secara langsung. Karena tidak semua jenazah yang dimandikan itu 
dalam keadaan yang 'bagus' anggota tubuh jenazahnya. Belum lagi ketika membersihkan kotorang si jenazah, mujahizah juga harus tahan dengan apapun yang mereka hadapi.

Ketika mengafani jenazah, mujahizah juga harus cerdas dan sigap. Cerdas yang dimaksud adalah tepat ketika mengukur kain kafan untuk jenazah. Karena setiap jenazah mempunyai ukuran yang berbeda-beda. Sehingga ketika jenazah yang sudah dimandikan diletakkan di atas kain kafan, tidak ada lagi istilah salah meletakkan kafan atau talinya. Sigapnya mujahizah ketika proses mengafani (termasuk memberikan bedak, kapas, dll) dilakukan dengan tepat tapi tidak kasar (dengan kelembutan).

Selain itu, mujahizah juga harus bijaksana dalam menghadapi tradisi-tradisi yang ada di keluarga yang sedang berduka. Mungkin ada keluarga yang ingin memandikan dan mengafani jenazahnya sendiri, dengan senang hati mujahizah mempersilakan. Atau jika perlu, sebelum mujahizah merawat jenazah ada baiknya menawarkan kepada pihak keluarga untuk merawat jenazah keluarga yang meninggal dunia, karena utamanya yang merawat jenazah adalah keluarga mereka sendiri. Selain itu, rahasia si jenazah juga akan lebih aman jika dirawat oleh anggota keluarga jenazah. Bukan berarti jika mujahizah yang merawat jenazah, rahasia tentang jenazah menjadi tidak aman tetapi alangkah lebih baiknya jika anggota keluarga yang merawat jenazah keluarganya.

Puncak dari mereka yang menjadi mujahizah adalah amanahnya. Di sinilah kredibelitas mujahizah dipertaruhkan. Di desa-desa biasanya mujahizah secara tidak sengaja menceritakan kekurangan jenazah pada orang lain. Hal-hal seperti inilah yang benar-benar harus dijaga. Oleh karena itu, bukan sembarang orang yang bisa dan mampu menyandang predikat sebagai mujahizah. Jika sifat dan sikap yang demikian itu dimiliki oleh mujahizah, maka sudah pasti akan tercetak mujahizah-mujahizah yang berkualitas. Sebaliknya, jika mujahizah tidak mempunyai sifat dan sikap tersebut sudah pasti image negatif mujahizah akan semakin kentara.

Pelatihan perawatan jenazah bagi mujahizah di wilayah Kecamatan Tembarak ini membawa pengaruh yang positif. Dimana pengaruh dapat kita pahami sebagai suatu perbedaan dalam pentuk prinsip, pola pikir, ataupun perilaku sebelum dan sesudah adanya treatment atau perlakuan. Program platihan dikatakan berhasil jika terjadi perubahan ke arah yang lebih baik.

Pengaruh yang muncul dalam pembentukan karakter para mujahizah, khususnya rasa keberanian, tanggung jawab, dan bijaksana. Hal tersebut merupakan efek atau pengaruh yang diharapkan dari sebuah program pendampingan. Efek yang muncul tercermin dalam dua bentuk yaitu perubahan mindset dan perubahan perilaku. Perubahan mindset adalah perubahan pola pikir dalam bentuk prinsip hidup yang lebih baik, misalkan adanya keinginan untuk menyakini bahwa memandikan jenazah itu tidaklah menakutkan. Sedangkan perubahan perilaku adalah wujud nyata dari adanya perubahan pola pikir yang diwujudkan dalam sebuah tindakan nyata.

Kondisi mindset dan perilaku para mujahizah sebelum adanya pelatihan perawatan jenazah adalah mereka menganggap bahwa tugas mengurus jenazah adalah tugas yang menakutkan dan mengerikan karena berhadapan langsung dengan jenazah. Mereka merasa khawatir dan takut ketika setelah merawat jenazah mereka terkena sawanen (sebutan penyakit untuk orang Jawa. Lebih kepada sakit yang disebabkan oleh hal-hal di luar nalar manusia) atau hal-hal lain. Dengan adanya pelatihan perawatan jenazah, yang menghadirkan pejabat dari Seksi Bimas Islam Kemenag Kabupaten Temanggung ini semakin membuka wawasan dan pengetahuan bagi mujahizah yang ada di wilayah Kecamatan Tembarak. Adanya praktik memandikan dan mengafani jenazah menambah kemantapan bagi mujahizah dalam merawat jenazah. Selain itu, video tutorial perawatan jenazah dapat memacu keingintahuan mujahizah manakala ingin belajar merawat jenazah ketika lupa.

Adapun pendampingan dilakukan dengan memberikan dorongan dan motivasi agar mereka bisa, mampu, dan berani praktik memandikan dan mengafani jenazah. Titik tekan yang disampaikan oleh nara sumber yakni terkait semangat mengurus jenazah sendiri bagi keluarga yang sedang berduka. Menjadi catatan tersendiri bagi mujahizah agar menyampaikan hal tersebut kepada masyarakat yang lain sekaligus membagikan pengetahuan dan keterampilan yang mereka dapatkan dalam pelatihan perawatan jenazah tersebut.

Selain pelatihan, kegiatan perawatan jenazah tersebut dilanjutkan dengan pendampingan. Pendampingan dari pelatihan perawatan jenazah dilakukan melalui pendampingan pembuatan video tutorial memandikan dan mengafani jenazah. Selain pendampingan pembuatan video tutorial 
tersebut, pendampingan juga dilakukan melalui grup WA yang di dalamnya terdapat semua peserta pelatihan, nara sumber, tim pengabdian, dan panitia pelatihan. Melalui grup tersebut, hal-hal yang menjadi kendala-kendala, atau segala sesuatu terkait perawatan jenazah atau fenomena-fenomena yang belum paham terkait perawatan jenazah ditanyakan di grup tersebut dan dijawab oleh nara sumber.

\section{KESIMPULAN}

Pendidikan Perawatan Jenazah bagi Perempuan di Kecamatan Tembarak Kabupaten Temanggung menghasikan sebuah istilah baru bagi perawat jenazah perempuan, yakni mujahizah. Pendidikan perawatan jenazajh bagi mujahizah di Kecamatan Tembarak Kabupaten Temanggung dilakukan melalui pelatihan perawatan jenazah, praktik memandikan dan mengafani jenazah, serta pembuatan video tutorial dalam memandikan dan mengafani jenazah. Melalui pengetahuan tentang perawatan jenazah, peserta yang terdiri atas mujahizah-mujahizah semakin membuka wawasan dan pengetahuan tentang bagaimana memperlakuan orang menjelang sakaratul maut, memperlakukan orang yang yang sudah meninggal dunia, memandikan, mengafani, menyalati dan mengubur jenazah.

Adapun pendampingan dilakukan dengan memberikan dorongan dan motivasi agar mereka mampu mempraktikkan perawatan jenazah melalui video tutorial hingga praktik menghadapi jenazah yang sesungguhnya. Karakter yang harus dimiliki oleh mujahizah diantaranya mereka harus sehat jasmani dan rohani, kuat dan tangguh, cakap dan sigap, terampil, berani, cerdas, bijaksana, dan amanah.

\section{DAFTAR PUSTAKA}

Bagian Pemerintah Setda Kabupaten Temanggung. 2017. Statistik Kabupaten Temanggung 2017. Temanggung: Dinas Komunikasi dan Informatika.

Dinas Kependudukan dan Pencatatan Sipil Kabupaten Temanggung. 2017. Statistik Kabupaten Temanggung 2017. Temanggung: Dinas Komunikasi dan Informatika. http://kbbi.kemendikbud.go.id

Kandepag Kabupaten Temanggung. 2013. Pelatihan Pembinaan Agama Islam. Temanggung: Seksi Urais Kandepag Kabupaten Temanggung.

Munawwir, Ahmad Warson. 1997. Al-Munawwir Kamus Arab-Indonesia. Surabaya: Pustaka Progressif.

Tim Penyusun Panduan KKN ABCD UIN Sunan Ampel Surabaya. 2015. Panduan KKN ABCD UIN Sunan Ampel Surabaya. Surabaya: LP2M UIN Sunan Ampel Surabaya.

Ulfa, Hidayatun dan Sholeh Kurniandini. 2019. Pembinaan Keahlian Perawatan Jenazah bagi Mujahizah (Studi Kasus di Kecamatan Tembarak Kabupaten Temanggung). Semarang: Pilar Nusantara. 